"Assessing the impact of structural indicators for the European Union banking system on economic evolution: an empirical investigation in EU"

\begin{tabular}{|c|c|}
\hline AUTHORS & $\begin{array}{l}\text { Syed Ahsan Jamil } \\
\text { Faris Nasif Al Shubiri }\end{array}$ \\
\hline ARTICLE INFO & $\begin{array}{l}\text { Syed Ahsan Jamil and Faris Nasif Al Shubiri (2016). Assessing the impact of } \\
\text { structural indicators for the European Union banking system on economic } \\
\text { evolution: an empirical investigation in EU. Banks and Bank Systems, 11(2), 61- } \\
\text { 69. doi:10.21511/bbs.11(2).2016.06 }\end{array}$ \\
\hline DOI & http://dx.doi.org/10.21511/bbs.11(2).2016.06 \\
\hline RELEASED ON & Saturday, 02 July 2016 \\
\hline JOURNAL & "Banks and Bank Systems" \\
\hline FOUNDER & LLC "Consulting Publishing Company "Business Perspectives" \\
\hline
\end{tabular}

NUMBER OF REFERENCES

0

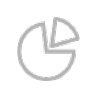

NUMBER OF FIGURES

0

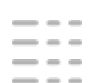

NUMBER OF TABLES

0

(C) The author(s) 2023. This publication is an open access article. 
Syed Ahsan Jamil (Sultanate of Oman), Faris Nasif Al Shubiri (Sultanate of Oman)

\title{
Assessing the impact of structural indicators for the European Union banking system on economic evolution: an empirical investigation in EU
}

\begin{abstract}
This study aims to investigate the impact of structural indicators for the European Union banking system on economic evolution. The methodological framework is the analysis of three variables of economic evolution. The econometric equation is built by regression test using annual data for the period 2008 to 2014. The indicators of the European banking system consist of fifteen independent variables and their impact on three economic variables consisting of GDP at current market prices, EMU convergence criterion bond yields (Maastricht criterion) and HICP annual average inflation rates are investigated on the growth in EU (dependent variable). The regression results show that there is statistical significant impact at different level 1\%, 5\% and $10 \%$ of all independent variables on EMU convergence criterion bond yields (Maastricht criterion), and in thirteen variables on GDP at current market prices except total assets of domestic banking groups and branches of credit institutions from rest of the world variables. Finally, only three variables total assets of domestic banking groups, branches of credit institutions from rest of the world and assets of pension funds have significant impact on HICP annual average inflation rates. The researchers recommend the need to build the financial stability in the banking system of the European Union with the continuity of modifying commercial legislation based on environmental changes and raise transparency to increase and diversify investments in the financial markets to reduce risk, and, thus, this will lead to increase in the level of social responsibility toward socialist economic.
\end{abstract}

Keywords: banking system, economic evolution, European Union.

JEL Classification: G20, O11, N14.

\section{Introduction}

Banks play a key role in the allocation of economic resources and affect the transfer of assets, payments system, fiscal policy and financial stability which are considrered as critical factors and drivers for the economic growth process. The recent acceleration in the assets of the financial sector, growth and unbalanced macroeconomic variables during the global financial crisi, led to the rise of the pertinent question about the size of the financial sector, effectiveness of its various activities, restrictions, costs imposed and its impact on the community's economy (Lakstutiene, 2008).

The magnitude of changes in the financial sector in the European Union has a significant impact on the level of competition in the market, which diagnosed the extent of the financial crisis, banks' interest in financial stability, competition and concentration in the market and the relationship between them. The global financial crisis that has occurred recently made the banks think about how to build strong and solid foundations, maintain stability and reliability in the banking system and, thus, make EU care about quality supervision and international

(c) Syed Ahsan Jamil, Faris Nasif Al-Shubiri, 2016.

Syed Ahsan Jamil, Associate Professor, Department of Accounting and Finance, College of Commerce and Business Administration, Dhofar University, Sultanate of Oman.

Faris Nasif Al-Shubiri, Assistant Professor, Department of Accounting and Finance, College of Commerce and Business Administration, Dhofar University, Sultanate of Oman. coordination in all its banking operations by upholding the restrictions and requirements of the BASEL III system. The European system is now trying to coordinate regulation of the financial and economic systems at EU level as a whole, rather than at the national level. One of the central pillars of the financial system is the control restrictions, coordination and supervision for the effectiveness of the financial system and it tries to find solutions to all the conflicts between the local financial sector, industry and banks. The evolution of the banking system has increasingly been reliant on non-interest income supported by technology up gradation and the level of freedom of information in the European Union contributed to amend the restrictions and dealing with the environment variables easily in light of financial and economic globalization (Dhameja, 2010).

The objective of this study is to understand the fluctuations within the financial banking system structure of EU countries and focus on changes in concentration and competition in the market and its subsequent impact on economic development within the ambit of EU regulations. The contribution of this study is to analyze factors that influence the financial structure of the banking system and are represented in the monetary policy of the European Union and, thus, focus on financial performance and the extent of its impact on the economy. The added value of the study is to crystallize the power of the banking financial position in light of competi- 
tion and cooperation within the European Union to overcome the environmental challenges and risks and to also analyze the development of information and communication technology that contributed for increasing the level of the creative phase of the banking system, which focused on the competitive advantages of the services provided to achieve efficiency in their operations. Hence, the importance of the study is to crystallize the bank's financial analysis and flexible rules reflected on the financial performance in a changing environmental conditions which contribute to increase in the level of their efficiency leading to cost reduction, better resource allocation, and, hence, it's positive impact on the country's economy growth.

This study is structured as follows. In section one, literature review of all relevant previous studies related to this topic has been discussed especially pertaining to the analysis of the banking system and the process of economic evolution in European Union (EU). The second section presents the research methodology and we discuss the proposed model, variables and hypotheses. In the third section, analysis is done using relevant tools like regression test, and the inferences draw from the analysis. In the final section, we present the conclusion of the entire study and future course of action.

\section{Literature review}

Bikker and Haaf (2002) focused on competition in the market and the degree of obstacles both inside and outside European region, and found that the banking sector is characterized by monopolistic competition within the European countries, but varies outside Europe depending on the nature of the markets. Durham (2004) pointed out that economic freedom is instrumental in attracting foreign investment, which, in turn, contributes to economic growth in the short-term, and cooperation between local and foreign institutions results in increases in the life of invetsment in medium-and long-term contributing to positive economic value on Gross Domestic Product (GDP). Kim et al. (2006) indicated that the ongoing restructuring of banking restrictions and instructions audit contribute to avoidance of the risks, especially in light of monopolistic competition, which positively affects the bank's earnings and plays a vital role in economic growth.

Bornhorst and Commander (2006) noted the need to increase the proportion of employment in the market, which will increase the level of economic growth with the help of wage increase by reviewing of the policies' work. Gischer and Stiele (2008) explained the importance of banks' returns for economic growth by focusing on monopolistic competition and found that small banks are more effective in their performance and are able to achieve market power, as compared to big banks. Jurajda and Terrell (2009) indicated that the human element is the key factor in explaining the rate of nonemployment, which is considered the capital of many countries that contributes positively to economic growth.

Rousseau and Wachtel (2011) states that the depth of financial analysis in the financial sector impacts positively on economic growth, as increased liquidity in the financial markets affects the economy by transfer of funds between markets and work, and the allocation of resources in the market. Costea (2012) noted that the "financial gap" consists of three variables: country budget, exchange rate and the interest rate that affect the banking sector policy in granting of loans and the percentage of defaults and thise impact on economic growth. Greenwood et al. (2013) empirically analyzed the application and indicated that the efficiency of the development of the financial sector increases by making use of productive resources and recycling them to keep low costs, thus, reflecting positively on economic growth, and pointed to the need to adopt global financial models of intermediation.

Fiordelisi and Marques (2013) found that the investment diversification and the production of multiple products have significant effect on risk reduction, which contributes to the improvement of the financial sector portfolio and increases economic growth. Bruno and Hauswald (2014) indicated that the financial characteristics of the banks have a positive impact on the banks' growth, which is reflected on increasing the market share of domestic and foreign banks and creates an innovative competition in the market. Škarea and Tomić (2014) indicated that innovation is an essential component to building long-term contracts in the industry and this step is essential for economic growth, as well as for growth of production and technology which are the key factor of innovation. The study also found that the performance is different between states and depends on the period of study and existing resources in the states.

Tang (2015) explained that flow of foreign direct investment in the European Union does not contribute directly on economic growth, while the evolution of financial markets contributes to increased economic growth leading to increased market share, as the interaction with foreign direct investment and financial markets contribute to the financing of the firms in a positive way. Škare and Lacmanović (2015) explained that the human capital plays an important role in the economic growth phenomena and, starting from focus on the education sector, 
teaching methods and ability of states to stimulate this sector, the effect will extend to all industrial sectors for enhanced economics growth. Ruggiero et al. (2015) pointed out that enhanced cooperation between EU states had added value for economic and build a strength sector in economics with the ability to solve many of the problems that can occur in the market. This study is similar to a number of previous studies in terms of methodology and objective and in terms of the diagnosis of economic growth factors, as indicated in some of the studies, like human element, educational sector, financial innovation, market structure, political legislative factor and high coordination and cooperation between member states contribute to the economic development. The current study varies with the method of application, where the researchers analyzed and evaluated the independent variables as a model integrated in the performance of banks in the European Union. This analysis has been applied to a number of economic variable, after the global financial crisis, while different previous studies used only one economic variable to show their effect on economic development.

1.1. The constraints and growth of the European Union banking system. The global financial crisis has proved that the equity ratio is low for banks to absorb losses in addition to the lack of proportionate and sufficient liquidity to cover potential crisis. The BASEL Committee III is seeking a stable financial banking system that is based on three pillars of capital adequacy, improves the ownership and debt ratio weights appropriate to reduce the risks, as well as keeps up liquidity in the short-term and long-term and takes into account the budget inflows and cash outflows (Jalilian et al., 2007). The financial crisis made it clear that the harmonization in the banking and financial system constraints the EU to reduce the interest on the national level in order to increase the stability of the bank and also increased interest deposits and insurance, which gives an indication of the ability of banks to lend and cooperate between EU member states, making these countries compete and increase confidence in the banking sector, despite the low level of loans granted during the financial crisis, within the European Union, under the balance of the growth of loans granted to individuals and firms (Pasiouras, 2008).

The lower yields to the banks relative to the normal capital returns are coupled with the cost to provide the same services in the financial market, put pressure on the competitiveness and reduce the profit margin. The desire of banks to build strong reserves too results in reduction in the yield of banks. The low margin lending leads to the attention of government bond yields and building an investment portfolio in light of the financial crisis and the risk of the country (Piotr et al., 2006). The potential growth opportunities in the European banking system are the result of integration between these countries. This provides an opportunity to improve the banking system efficiency by addressing the constraints of the system. Necessary changes in trade legislation which facilitate the divising of longterm contracts between banks and implementing an incentive based system for employees to help to encourage them to work effectively in maintaining the bank's assets and increase transparency (Boeri and Garibaldi, 2006).

The importance of the banking system for corporate finance plays a key role in the evolution of the European financial economics due to diversification in the portfolio financing with access to the bond and stock resulting in achieving the integration of all markets within EU. The size of the banking sector in EU-27 countries is asymmetrical, due to difference in the value and size of assets among the so-called old and new EU member states.

Low similarity among EU member countries in terms of the share of assets in each different bank to GDP, as indicated in European statistical report (2011, 2013 2015), points out that bank loans in the EU are the first source of external finance for individuals, businesses and industry and it has a significant impact on the business cycle, monetary policy and, therefore, affects the economic value too. The supervisory committees established within the European Union act as macroprudential and micro-prudential supervision for controling of systematic risk, ensuring stability of the financial system, focus on development of the sectors and examine its risks.

\section{Research methodology}

This study analyzes the structural indicators for the European Union banking system on economic evolution in the European Union over the period 20082014. The data used are collected from European statistical report $(2011,2013,2015)$ and report on financial structures from European central bank (2015).

2.1. The variables and model of the study. The study developed a main model and tested it based on three dependent variables which explain the economic evolution in European Union (EU) and fifteen independent variables which impact the structural indicators of the European Union banking system. The main equation is summarized and presented below:

Economic Evolution $\left(E E V_{i t}\right)=\alpha_{0}+\beta_{1} N C I_{i t}+\beta_{2}+$ $+T A D_{i t}+\beta_{3} F S B_{i t}+\beta_{4} S C I_{i t}+\beta_{5} B C I_{i t}+\beta_{6} P C I_{i t}+$ $+\beta_{7} P L B_{i t}+\beta_{8} E A M M_{i t}+\beta_{9} E A I F_{i t}+\beta_{10} A I C_{i t}+$ 
$+\beta_{11}++A P F_{i t}+\beta_{12} R_{A P F T A}+\beta_{13} R_{i t} A I C A_{i t}+$

$+\beta_{14} R A M F T A_{i t} \beta_{15}$ RAOFITA $_{i t}+€_{i t}$,

where $\left(E E V_{i t}\right)$ is measured by: (GDP: $\left.C M P\right)$, (EMU-CCBY: Maastricht Criterion), and (HICP: AAIR).

Notes: The dependent variables of economic evolution are: GDP at current market prices (GDP: CMP), EMU convergence criterion bond yields (Maastricht criterion), (EMU-CCBY: Maastricht criterion), HICP all-items, annual average inflation rates (HICP: AAIR).

The independent variables are: Number of Credit Institutions (NCI), Total Assets of Domestic Banking Groups (TAD), Foreign-Controlled Subsidiaries and Branches (FSB), Subsidiaries of Credit Institutions from rest of the world (SCI), Branches of Credit Institutions from rest of the world (BCI), Population Per Credit Institution (PCI), Population per Local Branch (PLB), Euro Area Money Market Funds (MMFs) (EAMM), Euro Area Investment Funds (excl. MMFs) (EAIF), Assets of Insurance Corporations (AIC), Assets of Pension Funds (APF), Ratio of Assets of Pension Funds to Total Assets of the financial sector (RAPFTA), Ratio of Assets of Insurance Corporations to Total Assets of the financial sector (RAICTA), Ratio of Assets of MFIs to Total Assets of the financial sector (RAMFTA), Ratio of Assets of Other Financial Institutions to Total Assets of the financial sector (RAOFITA).

2.2. Hypotheses. In order to study the problem, are identified three hypotheses based on fifteen independent variables (mentioned in section 2.1) and are summarized as follows:

H0-1: There is no statistical significant impact of each structural indicator for the European Union banking system variables on GDP at current market prices variable.
H0-2: There is no statistical significant impact of each structural indicator for the European Union banking system variables on EMU convergence criterion bond yields (Maastricht criterion) variable

H0-3: There is no statistical significant impact of each structural indicator for the European Union banking system variables on HICP (annual average inflation rates variable).

\section{Results and discussion}

3.1. Descriptive statistic analysis. Table 1 shows descriptive statistical analysis of fifteen independent variables which explain the structural indicator for the European Union banking system. The descriptive statistic results calculated by average of each independent variables on EU countries over the period 2008-2014 based on annual report of financial structures from European central bank (2015). The analysis shows that Germany is high in NCI and TAD variables, but Estonia is low in the same variables, Ireland is high in FSB, but Slovenia is low, Malta is high in SCI and BCI variables, but they are low in Lithuania, Slovenia and Finland. Greece has high PCI whereas it is low for Luxembourg, Estonia is high in PLB, but it is low in Cyprus, the EAMM is high in France and low for Estonia, Cyprus, Latvia and Lithuania, the EAIF is high in Luxembourg and low in Latvia, the AIC is high in France and low in Ireland, Cyprus and Malta, the APF is high in Netherlands and low in Ireland, Greece and Cyprus, the RAPFTA is high in Netherlands and low in France, Luxembourg and Malta, the RAICTA is high in France and low in Greece, the RAMFTA is high in Finland and low in Netherlands. Finally, the RAOFITA is high in Luxembourg and low in Greece. The interpretation of the result depicts that high evaluation of performance is concentrated in ten countries having a high GDP in addition to the multiple industries that are adding economic value and increasing growth in all financial activities.

Table 1. The statistical descriptive analysis of independent variables

\begin{tabular}{|c|c|c|c|c|}
\hline Independent variables & Minimum & Maximum & Mean & Std. deviation \\
\hline $\mathrm{NCl}$ & 258.0 & 319.00 & 295.1429 & 20.92390 \\
\hline$T A D$ & 1218.00 & 1488.00 & 1332.1429 & 82.43266 \\
\hline$F S B$ & 194.00 & 274.00 & 235.2857 & 29.94280 \\
\hline $\mathrm{SCl}$ & 4.00 & 7.00 & 5.5714 & 0.97590 \\
\hline $\mathrm{BCl}$ & 1.00 & 4.00 & 3.0000 & 1.00000 \\
\hline $\mathrm{PCl}$ & 65527.00 & 77051.00 & 69389.71 & 4416.60827 \\
\hline PLB & 2838.00 & 3906.00 & 3268.5714 & 401.41333 \\
\hline EAMM & 44.00 & 67.00 & 55.5714 & 8.65750 \\
\hline EAIF & 235.00 & 500.00 & 353.7143 & 87.53802 \\
\hline$A / C$ & 241.00 & 340.00 & 285.5714 & 33.24082 \\
\hline$A P F$ & 62.00 & 107.00 & 80.8571 & 15.57165 \\
\hline RAPFTA & 1.00 & 4.00 & 2.2857 & 1.11270 \\
\hline
\end{tabular}


Table 1 (cont.). The statistical descriptive analysis of independent variables

\begin{tabular}{|l|c|c|c|c|}
\hline \multicolumn{1}{|c|}{ Independent variables } & Minimum & Maximum & Mean & Std. deviation \\
\hline RAICTA & 4.00 & 8.00 & 6.1429 & 1.77281 \\
\hline RAMFTA & 42.00 & 65.00 & 53.7143 & 9.89468 \\
\hline RAOFITA & 11.00 & 26.00 & 19.7143 & 5.79409 \\
\hline
\end{tabular}

Table 2 shows descriptive statistical analysis of three dependent variables which explain the economic evolution in EU over the period of 2008 to 2014. The descriptive statistics results are based on data collected from the European statistical report of $(2011,2013,2015)$. The results indicated that GDP has increased relatively from 11770.00 in 2009 to 13921.00 in 2014, over the period of study, indicating an overall growth in all activities within EU due to harmonious cooperation with all sectors of the economy, harmonized economic policies and the importance of trade and economic agreements that are made with many countries, all of which contributed positively to economic growth. Also a gap between minimum and maximum number of the convergence criterion bond yields variable, that almost halled from 4.54 in 2008 to 2.21 in 2014 over the period because of the increasing growth of the industries and the private sector led to lower dependence on the public sector, leading to a decline in bond yields. Finally, the inflation rate in EU was fluctuating during the period of the study the minumim being in 2014 at 0.60 and high 3.70 in 2008. These results explain the balanced growth in all economic sectors of the European Union countries.

Table 2. The statistical descriptive analysis of dependent variables

\begin{tabular}{|l|c|c|c|c|}
\hline \multicolumn{1}{|c|}{ Dependent variables } & Minimum & Maximum & Mean & Std. deviation \\
\hline GDP: CMP & 11770.00 & 13921.00 & 12873.00 & 771.84670 \\
\hline EMU-CCBY: Maastricht criterion & 2.21 & 4.54 & 3.6571 & 0.81627 \\
\hline HICP: AAIR & 0.60 & 3.70 & 2.0857 & 1.12758 \\
\hline
\end{tabular}

3.2. Regression test and discussion. Table 3 focuses on the regression analysis, and the test run for all fifteen independent variables explaines the structural indicators for the European Union banking system on GDP at current market prices. The results how all variables are significant at $* *$ Sig at $p<0.05$ and $* * *$ Sig at $p<0.01$ except branches of credit institutions from rest of the world (BCI) and total assets of domestic banking groups (TAD) variables. The $t$-value significant variables are $-4.513,-3.197,6.027,5.634$, $5.841,-3.617,3.655,4.014,4.871,5.528,3.899,5.096$ and 3.622, where correlation $\mathrm{R}$ is high for all significant variables and the numbers lies between $85 \%$ and 93\%. Also $\mathrm{R}^{2}$ is high and lie between $67 \%$ and $85 \%$ for all significantly independent variables and is interpreted that coefficient of determination explained by amount of the dependent variable. The strong correlation is interpreted as due to the adoption of the EU's policy of compromise in the long run between industrial production and consumer needs, depending on the financial sector to increase economic growth while exploiting the power point in the European Union in the freedom and diversification of the market and high coordination between the EUcountries, example being the growth of the energy sector as a driver for the economic development in the European Union. The results explained that the GDP is the measure of the size of the economy and it is evident that growth in the EU was strong since 2008, primarily, due to its focus on the manufacturing sector, which was instrumental in maintaining its growth. Moreover, European Union was able to run leadership with a clear strategy, which gave priority to the Union's capital markets making the business attractive to the global investment sector. EU continuous attention towards a more democratic and flexible economic and monetary policy within the union led to increased growth reflected by steady increase in GDP. Indicators suggest that GDP returned to growth after 2009 at EU level and continued to increase to 3\% in 2014, reaching to an estimated EUR 13.9 trillion. This study is consistent with the previous study of Durham (2004) which emphasized on taking advantage of economic freedom in attracting foreign investment and its positive significant impact on GDP. This study also ratifies the findings by Hauswald (2014) about compatibility in terms of the presence of significant effect on the financial characteristics of economic development.

Table 3. Regression analysis of structural indicators for the European Union banking system on GDP at current market prices

\begin{tabular}{|c|c|c|c|c|c|c|}
\hline \multirow[t]{2}{*}{ Ind. var. } & \multirow[t]{2}{*}{$\mathrm{R}$} & \multirow[t]{2}{*}{$\mathrm{R}^{2}$} & \multirow[t]{2}{*}{ T-value } & \multirow[t]{2}{*}{ Sig. } & \multicolumn{2}{|c|}{ Un standardized coefficient } \\
\hline & & & & & St-Error & $B$ \\
\hline $\mathrm{NCl}$ & 0.896 & 0.803 & -4.513 & $0.006^{\star \star \star}$ & 7.324 & -33.054 \\
\hline
\end{tabular}


Table 3 (cont). Regression analysis of structural indicators for the European Union banking system on GDP at current market prices

\begin{tabular}{|c|c|c|c|c|c|c|}
\hline \multirow[t]{2}{*}{ Ind. var. } & \multirow[t]{2}{*}{$\mathrm{R}$} & \multirow[t]{2}{*}{$\mathrm{R}^{2}$} & \multirow[t]{2}{*}{ T- value } & \multirow[t]{2}{*}{ Sig. } & \multicolumn{2}{|c|}{ Un standardized coefficient } \\
\hline & & & & & St-Error & B \\
\hline$T A D$ & 0.510 & 0.260 & -1.324 & 0.243 & 3.603 & -4.771 \\
\hline$F S B$ & 0.819 & 0.671 & -3.197 & $0.024^{\star \star}$ & 6.607 & -21.123 \\
\hline $\mathrm{SCl}$ & 0.937 & 0.879 & 6.024 & $0.002^{\star \star \star}$ & 123.085 & 741.475 \\
\hline $\mathrm{BCl}$ & 0.529 & 0.280 & 1.395 & 0.222 & 292.874 & 408.500 \\
\hline $\mathrm{PCl}$ & 0.929 & 0.864 & 5.634 & $0.002^{\star \star \star}$ & 0.029 & 0.162 \\
\hline PLB & 0.934 & 0.872 & 5.841 & $0.002^{\star \star \star}$ & 0.307 & 1.795 \\
\hline EAMM & 0.851 & 0.724 & -3.617 & $0.015^{\star \star}$ & 20.964 & -75.835 \\
\hline EAIF & 0.853 & 0.728 & 3.655 & $0.015^{\star \star}$ & 2.058 & 7.521 \\
\hline AIC & 0.874 & 0.763 & 4.014 & $0.010^{* \star}$ & 5.054 & 20.285 \\
\hline$A P F$ & 0.909 & 0.826 & 4.871 & $0.005^{* \star *}$ & 9.247 & 45.048 \\
\hline RAPFTA & 0.927 & 0.859 & 5.528 & $0.003^{\star \star \star}$ & 116.325 & 643.058 \\
\hline RAICTA & 0.867 & 0.753 & 3.899 & $0.011^{\star *}$ & 96.863 & 377.682 \\
\hline RAMFTA & 0.916 & 0.839 & 5.096 & $0.004^{* * *}$ & 14.018 & 71.432 \\
\hline RAOFITA & 0.851 & 0.724 & 3.622 & $0.015^{\star \star}$ & 31.293 & 113.355 \\
\hline
\end{tabular}

Table 4 explains the regression analysis and also test run for all fifteen independent variables explained the structural indicators for the European Union banking system on EMU convergence criterion bond yields (Maastricht criterion). The results shows that all variables are significant at *Sig at $p<0.10 * *$ Sig at $p<0.05$ and $* * *$ Sig at $p<0.01$ significant level. The $t$-value significant variables are 6.746, $2.661,5.462,-2.316,-2.964,-5.659,-5.234,2.300$, $8.023,-7.063,-5.790,-4.824,-3.484,-2.693$ and 3.977, where, correlation $\mathrm{R}$ is high for all significant variables and the numbers between $71 \%$ and $96 \%$, and also $R^{2}$ is high and between $51 \%$ and $90 \%$ for all significantly independent variables and interpreted that coefficient of determination is explained by amount of the dependent variable. The strong correlation is interpreted as the European Union's ability to create easy mechanisms to handle any obstacles and economic crises emanating due to political barriers that limit economic variations and keeps the market and the financial sector at high efficiency, and where many economic agreements have contributed in promoting medium and long level of economic growth in all countries of European Union.

The interpreted results reflect that this indicator is important not only for economic development, but also is a key function in the evaluation of currency to the productivity gains from the commercial sector, where this comes not only from income, but also from loans by banks, thus, increasing reflecting the purchasing power problem which leads to deterioration of the economy, leading to inflation and the lack of balance in the market. Arising out of this phenomenon is the problem of risk premium when government increase revenues from bonds and lower exchange rates. The financial position, therefore, is negatively affected by this situation which affects the economic value-added tax returns. In addition, government debt is rising and, thus, increasing the risk to the state's economy, leading to imbalance between the government's financial policy, stability of the financial and banking sector, this standard allows, to some extent, by taking into account some of these hedge risks in the process convergence. The results show that bond yields were up during the global financial crisis at $4.54 \%$ in 2008 , when it began to decline after 2012 and reached in $2.21 \%$ in 2014. These results are consistent with a study of Costea (2012) in terms of the presence of significant effect on the state budget on economic development as indicated in Fiordelisi and Marques (2013) with the need to diversify its investments and cooperation of the private sector with the state economy to increase economic development.

Table 4. Regression analysis of structural indicators for the european union banking system on EMU convergence criterion bond yields (Maastricht criterion)

\begin{tabular}{|c|c|c|c|c|c|c|}
\hline \multirow[t]{2}{*}{ Ind. var. } & \multirow[t]{2}{*}{$\mathrm{R}$} & \multirow[t]{2}{*}{$\mathrm{R}^{2}$} & \multirow[t]{2}{*}{ T- value } & \multirow[t]{2}{*}{ Sig. } & \multicolumn{2}{|c|}{ Unstandardized coefficient } \\
\hline & & & & & St-error & B \\
\hline $\mathrm{NCl}$ & 0.949 & 0.901 & 6.746 & $0.001^{* \star *}$ & 0.005 & 3.703E-02 \\
\hline$T A D$ & 0.766 & 0.586 & 2.661 & $0.045^{\star \star}$ & 0.003 & $7.580 \mathrm{E}-03$ \\
\hline FSB & 0.925 & 0.856 & 5.462 & $0.003^{\star \star \star}$ & 0.005 & $2.523 \mathrm{E}-02$ \\
\hline $\mathrm{SCl}$ & 0.719 & 0.518 & -2.316 & $0.068^{*}$ & 0.260 & -0.602 \\
\hline $\mathrm{BCl}$ & 0.798 & 0.637 & -2.964 & $0.031^{* *}$ & 0.220 & -0.652 \\
\hline
\end{tabular}


Table 4 (cont.). Regression analysis of structural indicators for the european union banking system on EMU convergence criterion bond yields (Maastricht criterion)

\begin{tabular}{|c|c|c|c|c|c|c|}
\hline \multirow[t]{2}{*}{ Ind. var. } & \multirow[t]{2}{*}{$\mathrm{R}$} & \multirow[t]{2}{*}{$\mathrm{R}^{2}$} & \multirow[t]{2}{*}{ T- Value } & \multirow[t]{2}{*}{ Sig. } & \multicolumn{2}{|c|}{ Un standardized coefficient } \\
\hline & & & & & St-Error & B \\
\hline $\mathrm{PCl}$ & 0.930 & 0.865 & -5.659 & $0.002^{\star \star *}$ & 0.000 & $-1.72 \mathrm{E}-04$ \\
\hline$P L B$ & 0.920 & 0.846 & -5.234 & $0.003^{\star \star \star}$ & 0.000 & $-1.87 \mathrm{E}-03$ \\
\hline EAMM & 0.717 & 0.514 & 2.300 & $0.070^{*}$ & 0.029 & $6.760 \mathrm{E}-02$ \\
\hline EAIF & 0.963 & 0.928 & -8.023 & $0.000^{\star \star \star}$ & 0.001 & $-8.98 \mathrm{E}-03$ \\
\hline$A I C$ & 0.953 & 0.909 & -7.063 & $0.001^{\star \star \star}$ & 0.003 & $-2.34 \mathrm{E}-02$ \\
\hline$A P F$ & 0.933 & 0.870 & -5.790 & $0.002^{\star \star \star}$ & 0.008 & $-4.89 \mathrm{E}-02$ \\
\hline RAPFTA & 0.907 & 0.823 & -4.824 & $0.005^{\star \star \star}$ & 0.138 & -0.666 \\
\hline RAICTA & 0.842 & 0.708 & -3.484 & $0.018^{\star *}$ & 0.111 & -0.388 \\
\hline RAMFTA & 0.769 & 0.592 & -2.693 & $0.043^{\star \star}$ & 0.024 & $-6.35 \mathrm{E}-02$ \\
\hline RAOFITA & 0.872 & 0.760 & -3.977 & $0.011^{* *}$ & 0.031 & -0.123 \\
\hline
\end{tabular}

Table 5 indicated the regression analysis and the test run for all fifteen independent variables explained the structural indicators for the European Union banking system on HICP, annual average inflation rates. There are three variables consisting of branches of credit institutions from rest of the world (BCI), total assets of domestic banking groups (TAD) and assets of pension funds (APF) only are significant at *Sig at $p<0.10 * *$ and Sig at $p<0.05$. The $t$-value significant variables are $2.458,-2.818$ and -1.531 , where correlation $R$ is $0.740,0.783$ and 0.565 , while $R^{2}$ is $0.547,0.614$ and 0.319 and interpreted that coefficient of determination explained by amount of the dependent variable. The medium correlation interpreted between the financial system characteristics and inflation variable is the extent of interaction of European Union countries to adopt alternative policies and plans to reduce the risk of inflation with the ability of these countries to pay attention to culture and social responsibility, which again reflects positively on economic development.
The inflation is expressed as an increase in the general level of prices of goods and services in the economy, and is measured in European region by harmonized index of consumer prices (HICP). Thus, when the purchasing power goes down, it tantamount to inability to buy the same goods and services in the same monetary value as previously paid. HICP gradually decreased from 2011 to 2014 to stand at $0.6 \%$ in 2014. Romania witnessed the biggest increase in HICP to $54.7 \%$, between the years 2005 to 2014 , while Ireland recorded the lowest rise in the same period of $9.6 \%$. The overall change in the EU was $20.9 \%$. This study correspond to the study of Bornhorst and Commander (2006) in terms of attention of employment element and increasing wages in the market and, thus, have a significant effect on improving market demand and reduce the rate of inflation as indicated of Greenwood et al. (2013) that operational efficiency increase productivity and reduce costs, which affects positively and significantly on the balance of prices and market demand.

Table 5. Regression analysis of structural indicators for the European union banking system on HICP, annual average inflation rates

\begin{tabular}{|c|c|c|c|c|c|c|}
\hline \multirow[t]{2}{*}{ Ind. var. } & \multirow[t]{2}{*}{$\mathrm{R}$} & \multirow[t]{2}{*}{$\mathrm{R}^{2}$} & \multirow[t]{2}{*}{ T-value } & \multirow[t]{2}{*}{ Sig. } & \multicolumn{2}{|c|}{ Un standardized coefficient } \\
\hline & & & & & St-error & B \\
\hline $\mathrm{NCl}$ & 0.593 & 0.352 & 1.649 & 0.160 & 0.019 & $3.198 \mathrm{E}-02$ \\
\hline$T A D$ & 0.740 & 0.547 & 2.458 & $0.057^{\star}$ & 0.004 & $1.012 \mathrm{E}-02$ \\
\hline FSB & 0.615 & 0.378 & 1.743 & 0.142 & 0.013 & $2.315 \mathrm{E}-02$ \\
\hline $\mathrm{SCl}$ & 0.143 & 0.020 & -0.323 & 0.760 & 0.511 & -0.165 \\
\hline $\mathrm{BCl}$ & 0.783 & 0.614 & -2.818 & $0.037^{\star \star}$ & 0.313 & -0.883 \\
\hline $\mathrm{PCl}$ & 0.557 & 0.310 & -1.499 & 0.194 & 0.000 & $-1.42 \mathrm{E}-04$ \\
\hline$P L B$ & 0.524 & 0.275 & -1.376 & 0.227 & 0.001 & $-1.47 \mathrm{E}-03$ \\
\hline EAMM & 0.313 & 0.098 & 0.738 & 0.494 & 0.055 & $4.082 \mathrm{E}-02$ \\
\hline EAIF & 0.654 & 0.427 & -1.931 & 0.111 & 0.004 & $-8.42 \mathrm{E}-03$ \\
\hline$A I C$ & 0.633 & 0.401 & -1.828 & 0.127 & 0.012 & $-2.15 \mathrm{E}-02$ \\
\hline APF & 0.565 & 0.319 & -1.531 & $0.027^{\star \star}$ & 0.027 & $-4.09 \mathrm{E}-02$ \\
\hline RAPFTA & 0.474 & 0.225 & -1.205 & 0.282 & -0.399 & -0.481 \\
\hline RAICTA & 0.524 & 0.275 & -1.376 & 0.227 & 0.242 & -0.333 \\
\hline RAMFTA & 0.337 & 0.113 & -0.799 & 0.460 & 0.048 & $-3.84 \mathrm{E}-02$ \\
\hline RAOFITA & 0.549 & 0.302 & -1.470 & 0.202 & 0.073 & -0.107 \\
\hline
\end{tabular}




\section{Conclusion}

This study aims to investigate the impact of structural indicators for the European Union banking system on economic evolution over the period 2008 to 2014. This study used three dependent variables explained the economic evolution consists of GDP at current market prices, EMU convergence criterion bond yields (Maastricht criterion) and HICP annual average inflation rates and fifteen independent variables focused on banking system structure as mentioned in methodology section. The regression results shows that there are statistical significant impact at different level $1 \%, 5 \%$ and $10 \%$ of all independent variables on EMU convergence criterion bond yields (Maastricht criterion) and in thirteen variables on GDP at current market prices except total assets of domestic banking groups and branches of credit institutions from rest of the world. Finally, only three variables total assets of domestic banking groups, branches of credit institutions from rest of the world and assets of pension funds has significant impact on HICP annual average inflation rates.

These inferences drawn from the results indicate that credit growth plays a central role in nominal convergence process and there is a fluctuation of financial stability in EU throughout the period of study. The researchers recommends the need to build financial stability in the banking system in the European Union with the continuity of modifying commercial legislation in harmony with environmental changes and to increase transparency and, finally, the need for EU countries to emphasize on active coordination with the private sector of all firms sizes to stimulate and increase investments in the financial markets and diversify to reduce risk, this issue leads to increase in the level of social responsibility toward socialistic economic. In our opinion, future research could focus on studies in the banking and financial environment in the European Union with an analysis to find the impact on different variables subsidiaries which could be used for the diagnosis of economic performance. The financial and economic variables used in the study and derived from data reports for the period 2008-2014 are limited and, if data on other variables is available and used, the study scope will increase. This is a limitation of the present study. Finally, investigation on the role of political, legal and regulatory systems in facilitating the function of banking and economic growth may be analyzed in the future studies. Also, the analysis and classification of variables may be different to diagnose and explain the relationship between the structural indicators in European Union banks and economic development by using panel data test.

\section{References}

1. Bikker, J. and Haaf, K. (2002). Competition, Concentration and their Relationship: an Empirical Analysis of the Banking Industry, Journal of Banking and Finance, 26, pp. 2191-2214.

2. Boeri, T. and Garibaldi, P. (2006). Are Labour Markets in the New Member States Sufficiently Flexible for EMU? Journal of Banking and Finance, 30, pp. 1393-1407.

3. Bruno, V. and Hauswald, R. (2014). The Real Effect of Foreign Banks, Review of Finance, 18 (5), pp. 1683-1716.

4. Costea, A. (2012). Evaluating the Performance of Non-Banking Financial Institutions by the Means of C-Means Algorithm, Journal of US-China Public Administration, 9 (4), pp. 458-466.

5. Dhameja, N. (2010). Financial Crisis: Impact, Challenges and Way Out, Indian Journal of Industrial Relations, 45 (3), pp. 11-16.

6. Durham, J. (2004). Absorptive Capacity and the Effects of Foreign Direct Investment and Equity Foreign Portfolio Investment on Economic Growth, European Economic Review, 48 (2), pp. 285-306.

7. Eurostat Statistical Books. (2015). Key Figures on Europe, Luxembourg: Publications Office of the European Union, [online] Available at: http://europa.eu [Accessed 10 February 2016].

8. Eurostat Statistical Books. (2011). Key Figures on Europe, Luxembourg: Publications Office of the European Union, [online] Available at: http://europa.eu [Accessed 10 February 2016].

9. Eurostat Statistical Books. (2013). Key Figures on Europe, Luxembourg: Publications Office of the European Union, [online] Available at: http://europa.eu [Accessed 10 February 2016].

10. Fiordelisi, F. and Marques, D. (2013). Is Default Risk Systematic? Journal of Banking and Finance, 37 (6), pp. 2000-2010.

11. Greenwood, J., Sanchez, J. and Wang, C. (2013). Quantifying the Impact of Financial Development on Economic Development, Review of Economic Dynamics, 16, pp. 194-215.

12. Gischer, H. and Stiele, M. (2008). Competition Tests with a Non-Structural Model: the Panzar-Rosse Method Applied to Germany's Savings Banks, German Economic Review, 10, pp. 50-70.

13. Jalilian, H., Kirkpatrick, C. and Parker, D. (2007). The Impact of Regulation on Economic Growth in Developing Countries: A Cross-Country Analysis, World Development, 35 (1), pp. 87-103.

14. Jurajda, Š. and Terrell, K. (2009). Regional Unemployment and Human Capital in Transition Economies, Economics of Transition, 17, pp. 241-274.

15. Kim, S., Moshirian, F. and Wu, E. (2006). Evolution of International Stock and Bond Market Integration: Influence of the European Monetary Union, Journal of Banking \& Finance, 30 (5), pp. 1507-1534. 
16. Lakstutiene, A. (2008). Correlation of the Indicators of the Financial System and Gross Domestic Product in European Union Countries, Engineering Economics, 3, pp. 7-18.

17. Pasiouras, F. (2008). International Evidence on the Impact of Regulations and Supervision on Banks Technical Efficiency: An Application of two-stage Data Envelopment Analysis, Review of Quantitative Finance and Accounting, 30 (2), pp. 187-223.

18. Piotr, B. and Bielicki, G. (2006). The Case for Defending a Host Supervisor's Powers, Global Risk Regulator, 4 (1), pp. 21-23.

19. Report on Financial Structures. (2015). European Central Bank, [online] Available at: www.ecb.europa.eu [Accessed 10 February 2016].

20. Rousseau, P. and Wachtel, P. (2011). What is Happening to the Impact of Financial Deepening on Economic Growth? Economic Inquiry, 49 (1), pp. 276-288.

21. Ruggiero, F., Vlad, L., Vlăsceanu, G. Gavriș, A. and Vasile, D. (2015). Energy Cooperation - The Strength of the EU's Economic Development. Amfiteatru Economic, 17 (40), pp. 1080-1094.

22. Škare, M. and Lacmanović, S. (2015). Human capital and economic growth: a review essay, Amfiteatru Economic, 17 (39), pp. 735-760

23. Škare, M. and Tomić, D. (2014). Examining the Link between Innovation, Productivity and Growth: A global View, Amfiteatru Economic, 16 (36), pp. 606-624.

24. Tang, D. (2015). Has the Foreign Direct Investment Boosted Economic Growth in the European Union Countries? Journal of International and Global Economic Studies, 8 (1), pp. 21-50. 